\title{
Pseudoaneurysm of aortocoronary vein graft secondary to late venous rupture: case report and literature review
}

\author{
Panny Kallis, Bruce E Keogh, Michael J Davies
}

Department of

Surgery, St George's

Hospital, London

P Kallis

B E Keogh

Department of

Histopathology,

St George's Hospital

Medical School,

London

M J Davies

Correspondence to:

Mr P Kallis, FRCS,

Department of

Cardiothoracic Surgery,

Harefield Hospital,

Harefield, Middlese

UB9 6JH.

Accepted for publication

23 March 1993

\begin{abstract}
Formation of pseudoaneurysms of saphenous vein grafts after coronary artery bypass grafting has been reported previously in relation to anastomoses or secondary to infection. Pseudoaneurysm of the saphenous vein graft after late rupture of the saphenous vein and containment by the obliterated pericardial cavity has not been documented. Such a case is reported and published reports of similar cases are reviewed.
\end{abstract}

(Br Heart f 1993;70:189-192)

True aneurysmal dilatation of the saphenous vein after myocardial revascularisation is rare and is usually secondary to atherosclerosis. ${ }^{1-5}$

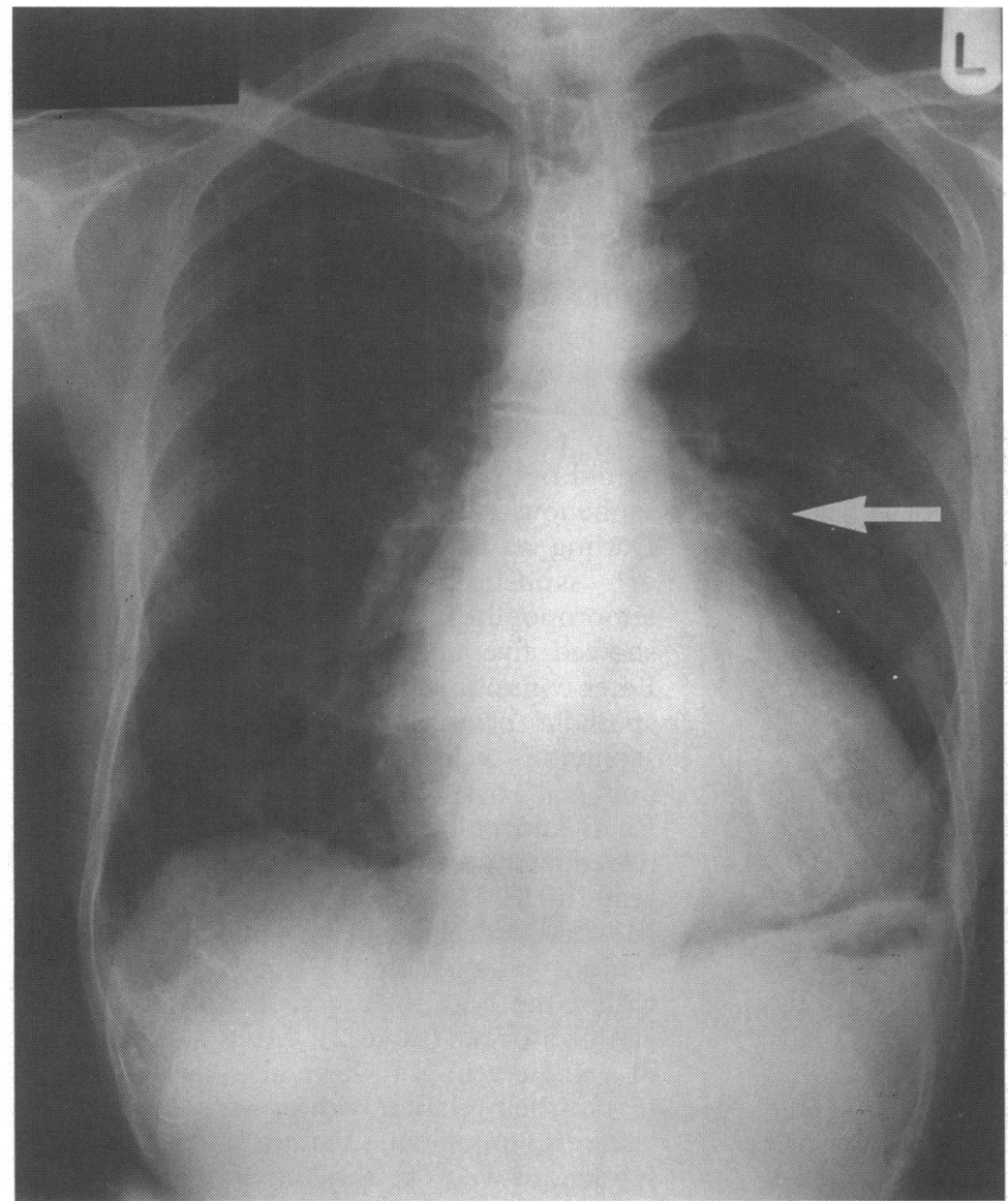

Figure 1 Chest radiograph showing a $3 \mathrm{~cm}$ round mass overlying the left side of the main pulmonary artery.
Formation of false aneurysm at the suture lines secondary to infection or technical error has also been reported. ${ }^{6-11}$ Late rupture of the body of the saphenous vein graft and containment by the obliterated pericardial cavity leading to the formation of a false aneurysm has not been reported previously. We report such a case presenting 13 years after coronary artery bypass grafting as well as a review of reports of other such cases. The different modes of presentation, possible complications, proposed mechanisms of formation, and management recommendations are discussed.

\section{Case report}

A 45 year old man presented in 1977 with angina and was found to have triple vessel and mixed aortic valve disease. He underwent quadruple coronary artery bypass grafting with a reversed saphenous vein, which was noted to be of good quality and calibre at the time. His aortic valve was replaced with a 25 $\mathrm{mm}$ Carpentier-Edwards xenograft and the mitral valve was noted to be normal. Three weeks later he developed Staphylococcus epidermidis endocarditis which resulted in emergency reoperation for severe aortic regurgitation. The valve had become detached from the non-coronary sinus and it was replaced with a $2.4 \mathrm{~cm}$ fresh homograft. Two days after the operation, after a respiratory arrest, the patient underwent emergency tracheostomy and insertion of a left chest drain for pneumothorax. An emergency thoracotomy was also performed for bleeding from the chest drain. Six weeks later he was discharged home apyrexial with a normal white cell count.

Ten years later he developed dyspnoea on minimal exertion and cardiac catheterisation confirmed severe aortic regurgitation. All four vein grafts were patent, with some atheroma, but with neither critical stenoses nor aneurysmal dilatation. He underwent aortic valve replacement for perforation of the left coronary cusp of the homograft with a size $9 \mathrm{~A}$ Starr-Edwards prosthesis.

Three years later, at the age of 58 , he once again presented with dyspnoea on exertion and was noted to have severe aortic regurgitation. His chest radiograph showed a small mass overlying the left side of the pulmonary artery (fig 1), which was not evident on chest radiographs for the first year after his previous operation. A computed tomogram confirmed a $3 \mathrm{~cm}$ mass on the left side of the pulmonary 
Figure 2 Computed showing a $3 \mathrm{~cm}$ mass adjacent to the main pulmonary artery. tomogram of the thorax

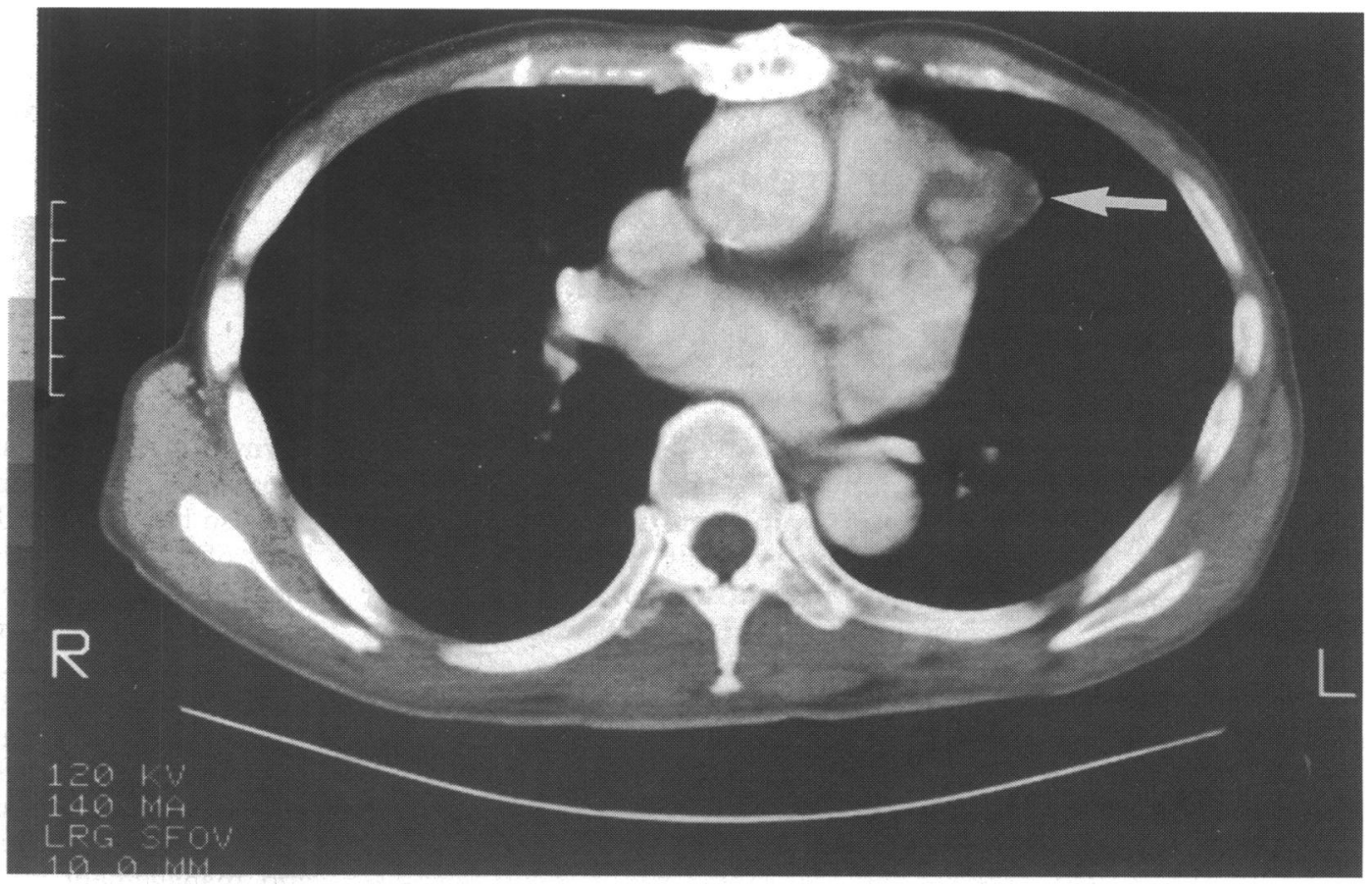

artery (fig 2). Cardiac catheterisation showed severe aortic regurgitation and critical stenoses of the vein grafts to the right, the left anterior descending, and diagonal coronary arteries. Angiography of the vein graft to the obtuse marginal branch of the circumflex artery had shown a saccular aneurysm but no critical stenosis (fig 3).

At operation the aortic prosthesis was found to have partially dehisced and was replaced with a size $11 \mathrm{~A}$ Starr-Edwards valve with concomitant triple coronary artery bypass grafts. The aneurysmal part of the vein graft was resected after proximal and distal ligation. After operation he required inotropic support and intra aortic balloon counterpulsation but died 24 hours later from

Figure 3 Preoperative coronary angiogram showing a saccular aneurysm of the saphenous vein graft. low cardiac output.

Histopathological examination of the saphenous vein graft showed complete rupture of the intima and media with the ruptured ends folded back (figs 4 and 5). This was contained by the obliterated pericardial cavity and a $2 \mathrm{~cm}$ false aneurysm of the body of the saphenous vein graft was formed that contained thrombus. Microscopy of the vein graft at other sites showed some intimal atherosclerosis.

\section{Discussion}

In 1968 Dedominico and colleagues ${ }^{12}$ reported the development of aneurysms in external jugular veins used in experimental coronary artery bypass grafting in dogs five years after implantation. Despite this finding it was initially postulated that aneurysmal dilatation would not occur in the thicker walled human saphenous veins. This was confirmed by Darling et $a l^{13}$ in an angiographic study of saphenous veins used for 295 femoropopliteal bypass grafts that only showed five anastomotic pseudoaneurysms. Later communications, however, reported the sporadic occurrence of aneurysms of the saphenous vein after carotid ${ }^{14}$ and femoropopliteal bypass surgery. ${ }^{15,16}$ Subsequently Riahi and colleagues first reported aneurysmal dilatation of a coronary saphenous vein graft in $1975^{1}$ although these remain rare. Most are pseudoaneurysms occurring at anastomotic sites (table 1) but true aneurysms within the body of the saphenous vein graft can also occur (table 2). Multiple aneurysms of a single vein graft have also been reported ${ }^{3}$ 520 but their relation with pre-existing varicose veins is unknown. Failure to reverse the saphenous vein at the time of grafting has been proposed as a possible cause of multiple aneurysms. ${ }^{3}$

The mechanisms of formation remain 


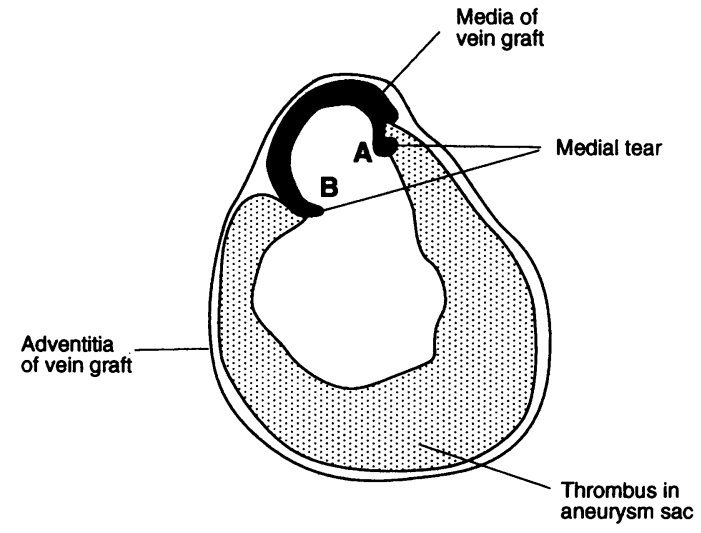

Figure 4 Drawing of a cross section of the aneurysm of the saphenous vein graft showing complete rupture of the intima and media of the vein with the ruptured ends folded back ( $A$ and $B)$. The sac of the pseudoaneurysm containing thrombus is also shown.

unclear but the following causative factors have been postulated: hypertension, trauma to the vein at the time of operation, vein necrosis, weakness at a branch site, weakness in the area of valves secondary to absence of circular muscle in the media, coronary steal secondary to a fistula, thrombosis, atherosclerotic change within the graft, mycotic vasculitis, and dissection of the saphenous vein graft (tables 1 and 2). Several factors seem to play a part in the formation of saphenous vein graft aneurysms which may occur as early as 12 days $^{17}$ or as late as 17 years after surgery. ${ }^{16}$

Figure 5 Microscopical examination of the two ends of the ruptured media ( $A$ and $B$ in fig 4). Stained with elastic-van Gieson, magnification originally $\times 40$

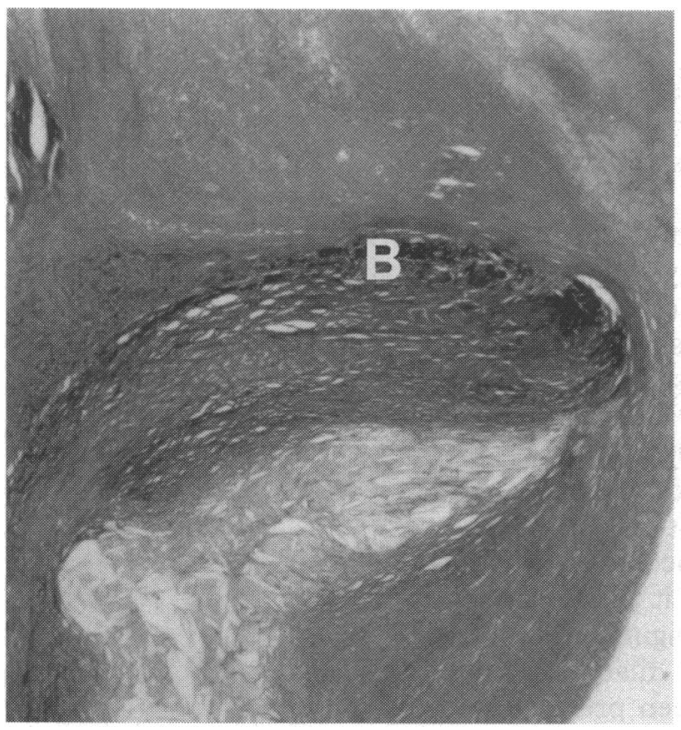

The early aneurysms are more likely to be false and due to infection or operative factors, whereas those of late onset are more likely to be due to atherosclerosis especially in patients with hyperlipidaemia. ${ }^{20}$

Our case shows a new mechanism of formation of a saphenous vein graft aneurysm. Rupture of the vein graft must have occurred one to three years after the third operation because there was no preoperative angiographic evidence of aneurysmal dilatation. Furthermore serial chest radiographs after operation for the first year did not show the aneurysm overlying the pulmonary artery as shown two years later (figs 1 and 2). Late rupture (11-13 years) of the body of the saphenous vein graft into the pericardial cavity was contained, as a result of adhesions from the previous three operations, leading to formation of a false aneurysm. The fact that the pericardial cavity was obliterated also prevented fatal haemorrhage or cardiac tamponade. The most plausible mechanism of rupture of the saphenous vein graft is weakness of the wall of the vein secondary to atherosclerotic changes.

Saphenous vein graft aneurysms can present in a variety of ways such as a large mediastinal mass ${ }^{1821}$ or as an enlarging pulsatile mass over the xiphoid. ${ }^{19}$ The reported complications include rupture, ${ }^{722}$ symptomatic coronary embolisation, ${ }^{23}$ fatal dehiscence secondary to bacterial infection, ${ }^{17}$ and formation of a fistula between the vein graft and the

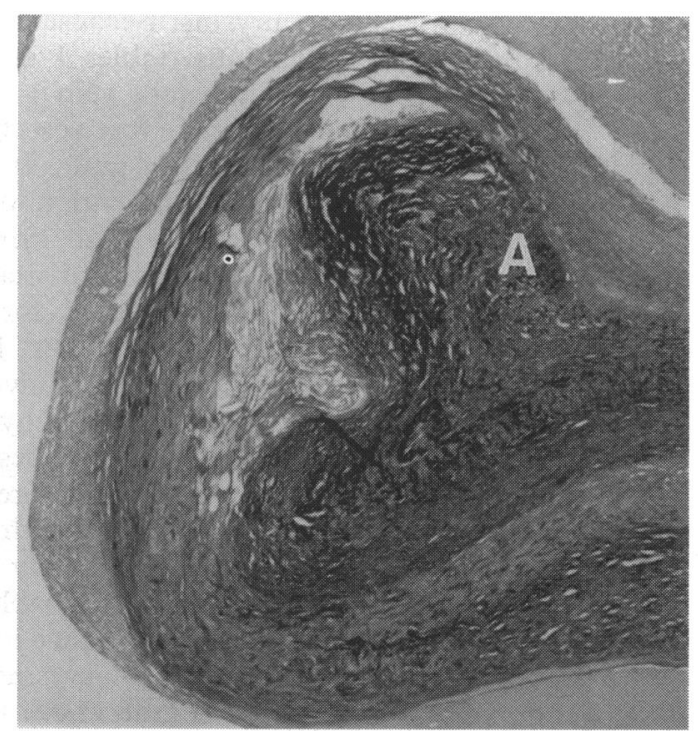

Table 1 False coronary vein graft aneurysms

\begin{tabular}{|c|c|c|c|c|c|}
\hline Authors & Time & Mode of presentation & Management & Outcome & Postulated mechanism \\
\hline Shapeero et al ${ }^{6}$ & $9 \mathrm{yr}$ & $\begin{array}{l}\text { Myocardial infarction, } \\
\text { mediastinal mass, rupture }\end{array}$ & Coil occlusion & Survived & - \\
\hline $\begin{array}{l}\text { Yousem et al } 7 \\
\text { Kazui et al }\end{array}$ & $\begin{array}{l}5 \text { yr } \\
2-4 \text { yr } \\
2 \text { patients }\end{array}$ & $\begin{array}{l}\text { Mediastinal mass, rupture } \\
\text { Recurrent angina }\end{array}$ & $\begin{array}{l}\text { Conservative } \\
\text { Resection and CABG }\end{array}$ & $\begin{array}{l}\text { Died } \\
\text { Survived }\end{array}$ & $\begin{array}{l}\text { Vasculitis } \\
\text { Trauma at operation }\end{array}$ \\
\hline Sherry et al ${ }^{9}$ & $\begin{array}{l}13-15 \mathrm{yr} \\
2 \text { patients }\end{array}$ & Recurrent angina & - & - & - \\
\hline $\begin{array}{l}\text { De Haan et al }{ }^{10} \\
\text { Ducksoo et al }{ }^{11}\end{array}$ & $\begin{array}{l}\text { A few days } \\
9 \mathrm{yr}\end{array}$ & $\begin{array}{l}\text { Routine early angiogram } \\
\text { Myocardial infarction, } \\
\text { mediastinal mass }\end{array}$ & $\begin{array}{l}\text { Resection and CABG } \\
\text { Coil occlusion }\end{array}$ & $\begin{array}{l}\text { Survived } \\
\text { Survived }\end{array}$ & $\begin{array}{l}\text { Tear of stitches at distal anastomoses } \\
-\end{array}$ \\
\hline Douglas et al ${ }^{17}$ & 12 days & $\begin{array}{l}\text { Rupture of proximal } \\
\text { anastomosis }\end{array}$ & $\begin{array}{l}\text { Emergency reoperation } \\
\text { and control of bleeding }\end{array}$ & Died & Mediastinitis \\
\hline $\begin{array}{l}\text { Forster et al }{ }^{18} \\
\text { Smith and Goldstein }{ }^{19}\end{array}$ & $\begin{array}{l}17 \mathrm{yr} \\
2 \text { months }\end{array}$ & $\begin{array}{l}\text { Large mediastinal mass } \\
\text { Pulsatile mass over xiphoid }\end{array}$ & $\begin{array}{l}\text { Resection } \\
\text { Resection }\end{array}$ & $\overline{\text { Survived }}$ & $\bar{M}$ ediastinitis \\
\hline
\end{tabular}

CABG, coronary artery bypass grafting. 
Table 2 True coronary vein graft aneurysms

\begin{tabular}{|c|c|c|c|c|c|}
\hline Authors & Time & Mode of presentation & Management & Outcome & Postulated mechanism \\
\hline $\begin{array}{l}\text { Riahi et al }{ }^{1} \\
\text { Pintar et al }{ }^{2}\end{array}$ & $\begin{array}{l}6 \text { months } \\
5-6 \text { yr } \\
2 \text { patients }\end{array}$ & $\begin{array}{l}\text { Aortic regurgitation } \\
\text { Recurrent angina }\end{array}$ & $\begin{array}{l}\text { Resection and CABG } \\
\text { Resection and CABG }\end{array}$ & $\begin{array}{l}\text { Survived } \\
\text { Survived }\end{array}$ & $\overline{\text { Atherosclerotic }}$ \\
\hline Benchimol et al ${ }^{3}$ & 3 months & Symptom free, multiple & Conservative & Survived & $\begin{array}{l}\text { Failure to reverse vein, } \\
\text { muscle weakness near valves }\end{array}$ \\
\hline Bramlet et al ${ }^{4}$ & $5 \mathrm{yr}$ & Unstable angina & Conservative & Died & $\begin{array}{l}\text { Dissection of body of SVG, } \\
\text { hypertension, trauma, necrosis }\end{array}$ \\
\hline Liang et al ${ }^{5}$ & $\begin{array}{l}6-10 \mathrm{yr} \\
5 \text { patients }\end{array}$ & $\begin{array}{l}\text { Recurrent angina, } \\
\text { multiple aneurysms }\end{array}$ & Resection and CABG & - & $\begin{array}{l}\text { Atherosclerotic (4) } \\
\text { dissection of body of SVG (1) }\end{array}$ \\
\hline Teja et al ${ }^{20}$ & $14 \mathrm{yr}$ & $\begin{array}{l}\text { necropsy, } \\
\text { multiple aneurysms }\end{array}$ & - & Died & Atherosclerotic \\
\hline $\begin{array}{l}\text { Lopez Velardo et al } \\
\text { Murphy et al }\end{array}$ & $\begin{array}{l}15 \mathrm{yr} \\
14 \mathrm{yr}\end{array}$ & $\begin{array}{l}\text { Large mediastinal mass } \\
\text { Rupture, } \\
\text { large haemothorax }\end{array}$ & $\begin{array}{l}\text { Resection } \\
\text { Resection }\end{array}$ & $\begin{array}{l}\text { Died } \\
\text { Survived }\end{array}$ & Atherosclerotic \\
\hline Talierco et al ${ }^{23}$ & $9 \mathrm{yr}$ & $\begin{array}{l}\text { Symptomatic coronary } \\
\text { embolisation }\end{array}$ & Resection and CABG & Survived & - \\
\hline Riahi et al ${ }^{24}$ & $10 \mathrm{yr}$ & $\begin{array}{l}\text { Fistula between } \\
\text { SVG and RV }\end{array}$ & $\begin{array}{l}\text { Resection, CABG, } \\
\text { and closure of fistula }\end{array}$ & Died & Atherosclerotic \\
\hline Dzavic et al ${ }^{25}$ & $13 \mathrm{yr}$ & Myocardial infarction & Conservative & Died & - \\
\hline
\end{tabular}

CABG, coronary artery bypass grafting; RV, right ventricle; SVG, saphenous vein graft.

right ventricle. ${ }^{24}$

As most aneurysms of saphenous vein grafts remain undiscovered their true incidence and natural time course are likely to remain unknown. As a result it is difficult to formulate rigid management policies for this pathology but some guidelines can be put forward in the light of reported cases. In the presence of another cardiac pathology requiring surgical intervention the aneurysm should be resected at the same time even if there is no restriction to flow in the vein graft involved. Although successful coil occlusion treatment for controlling haemorrhage from an aneurysm of the saphenous vein graft has been reported, ${ }^{611}$ surgery remains the treatment of choice for the complicated aneurysms. Because of the likelihood of complications (tables 1 and 2) a large aneurysm with a patent vein graft should probably be considered for resection and replacement with another graft. It is difficult to propose clear recommendations regarding the management of small symptom free aneurysms discovered coincidentally, but they should at least be observed for changes in size and complications. This has been successfully performed by non-invasive methods such as computed tomography, ${ }^{67}$ magnetic resonance imaging, ${ }^{9}$ and transoesophageal echocardiography. ${ }^{25}$ It is even more difficult to know what should be done with the aneurysmal vein graft that has already occluded distal to the aneurysm, but probably it should be followed up with non-invasive imaging.

Although aneurysmal dilatations of saphenous vein grafts have been previously reported this is, to our knowledge, the first reported case of false aneurysm formation after late rupture of the body of the vein graft.

We thank Mr D J Parker for his useful contribution in writing this paper.

1 Riahi M, Vasu CM, Tomatis LA, Schlosser RJ, Zimmerman G. Aneurysm of saphenous vein bypas graft to coronary artery. $\mathcal{F}$ Thorac Cardiovasc Surg 1975 70:358-9.

2 Pintar K, Barboriak J, Johnson WD, Eddy D. Atherosclerotic aneurysm in aortocoronary vein graft. Arch Pathol Lab Med 1978;102:287-8.

3 Benchimol A, Harris CL, Desser KB, Fleming H. Aneurysms of an aortocoronary artery saphenous vein bypass graft-A case report. Vasc Surg 1975;9:261-4.

4 Bramlet DA, Behar VS, Ideker RE. Aneurysm of a saphe- nous vein bypass graft associated with aneurysms of native coronary arteries. Cathet Cardiovasc Diagn 1982; 8:489-94.

5 Liang BT, Antman EM, Taus R, Collins JJ, Schoen FJ. Atherosclerotic aneurysms of aortocoronary vein grafts. Am $\mathcal{F}$ Cardiol 1988;61:185-8.

6 Shapeero LG, Guthaner DF, Swerdlow CD, Wexler L. Rupture of a coronary bypass graft aneurysm: CT evaluation and coil occlusion therapy. $A F R A m \&$ Roentgenol 1983;141:1060-2.

7 Yousem D, Scott WJr, Fishman EK, Watson AJ, Traill T, Gimenez L. Saphenous vein graft aneurysms demonstrated by computed tomography. $\mathcal{f}$ Comput Assist Tomogr 1986;3:526-8.

8 Kazui T, Harada H, Komatsu S. Saphenous vein aneurysm following coronary artery bypass grafting. $\mathcal{F}$ Cardiovasc Surg 1988;29:364-7.

9 Sherry CS, Harms SE. MR imaging of pseudoaneurysms in aortocoronary bypass graft. F Comput Assist Tomogr 1989;13:426-9.

10 De Haan HPJ, Huysmans HA, Weeda HWH, Bosker HA, Buis B. Anastomotic pseudoaneurysm after aortocoronary bypass grafting. Thorac Cardiovasc Surg 1985; 33:55-6.

11 Ducksoo K, Guthaner DF, Wexler L. Transcatheter embolisation of a leaking pseudoaneurysm of saphenous vein aortocoronary bypass graft. Cathet Cardiovasc Diagn 1983;9:591-4.

12 Dedominico M, Sameh AA, Berger K, Wood SJ, Sauvage LR. Experimental coronary artery surgery. Long term follow up, bypass venous autografts, longitudinal arterifollowip, and end to end anastomoses. $₹$ Thorac otomies, and end to end anas
Cardiovasc Surg 1968;56:617-23.

13 Darling RC, Linton RR, Razzuk MA. Saphenous vein bypass grafts for femoropopliteal occlusive disease: reappraisal. Surgery 1967;61:31-40.

14 Carrasquilla C, Weaver AW. Aneurysm of saphenous vein grafts to the common carotid artery. Vasc Surg 1972;6:66-8.

15 De La Rocha AG, Peixoto RS, Baird RJ. Atherosclerosis and aneurysm formation in a saphenous vein graft. $\mathrm{Br} \mathcal{F}$ Surg 1973;60:72-3.

16 Davidson ED, DePalma RG. Atherosclerotic aneurysm occurring in an autogenous vein graft. Am f Surg 1972; 124:112-4.

17 Douglas BP, Bulkley BH, Hutchins GM. Infected saphenous vein coronary artery bypass graft with mycotic aneurysm. Fatal dehiscence of the proximal anastomosis. Chest 1979;75:76-7.

18 Forster DA, Haupert MS. Large mediastinal mass secondary to an aortocoronary saphenous vein bypass graft

19 Smith JA, Goldstein J. Saphenous vein graft pseudoaneurysm formation after postoperative mediastinitis. aneurysm formation after posto

20 Teja K, Dillingham R, Mentzer RM. Saphenous vein aneurysms after aortocoronary bypass grafting: Postoperative interval and hyperlipidemia as determining factors. Am Heart $\mathcal{f}$ 1987;113:1527-9.

21 Lopez-Velarde P, Hallman GL, Treistman B. Aneurysm of an aortocoronary saphenous vein bypass graft presenting as an anterior mediastinal mass. Ann Thorac Surg 1988;46:349-50.

22 Murphy JPJr, Shabb B, Nishikawa A, Adams PR, Walker WE. Rupture of an aortocoronary saphenous vein graft aneurysm. Am f Cardiol 1986;58:555-7.

23 Taliercio CP, Smith HC, Pluth JR, Gibbons RJ. Coronary artery venous bypass graft aneurysm with symptomatic
coronary artery emboli. Am Coll Cardiol 1986;7:435-7.

24 Riahi M, Stone KS, Hanni CL, Fierens E, Dean RE. Right ventricular-saphenous vein graft fistula: unusual complication of aortocoronary bypass grafting. $¥$ Thorac Cardiovasc Surg 1984;87:626-8.

25 Dzavic V, Lemay M, Chan KL. Echocardiographic diagnosis of an aortocoronary venous bypass graft aneurysm. Am Heart $₹$ 1989;118:619-21. 